\title{
A Community of Collaboration
}

\section{Andie Craley}

Andie Craley is Manager for Technical Services and Government Documents Librarian at Harford Community College Library.

Correspondence concerning this column should be addressed to Marianne Ryan, Dean of Libraries, Loyola University Chicago, 1032 W. Sheridan Road, Chicago, IL 60660; email: mryan21@luc.edu.
Most of us are familiar with the scenario of institutional belttightening and the effect that it sometimes has on staffing. Reductions and reallocations of human resources can make it difficult to accomplish our work and can affect moralebut not always. In this column, Andie Craley describes the net positives of that experience at her institution. While still facing the reality of doing more with less, Craley identifies how its inherent challenges can present definite opportunities and foster a community of collaboration.-Editor

$\mathrm{H}$ aving started as a library technician at Harford Community College Library (HCC Library) just seventeen years ago, I already find myself the third in seniority. Library staff size seems to diminish as additional job functions are assimilated into existing positions, reallocated as new library services are introduced, redeployed to other departments, or completely eliminated as staff retire or resign. The concept of wearing many hats is common, as is the expectation to take on "other duties as assigned." From networking with colleagues at other Maryland community college libraries, I know this situation is not unique. The current staffing reality both mirrors the evolution of the library's facilities and demands doing more with less, but it also provides individual and collective opportunities for growth, supporting a community of collaboration.

\section{EVOLUTION OF THE LIBRARY}

When then Harford Junior College (HJC) was established in 1957, classes were held at a nearby high school and the library was a small, shelved book collection. HJC moved to its own campus in 1964 and, three years later, the HJC Library was designated as a Federal Depository Library. As HJC grew into HCC, the library moved into the Learning Resources Center in 1976. That space was later renovated as the Student Center to allow the co-location of most student support services in one place. In 2000, the library moved to its current building, sharing space with the campus's Computer Technology Services and the president's office. ${ }^{1}$

The new HCC Library featured three floors containing a digital library lab with distance learning assistance, computer classrooms, patron computers, study rooms, circulation, and reference materials. Over time, Computer Technology Services and the president's office were relocated, library technicians working with distance learning became a separate department called eLearning with its own director in a remote location, and the office of Institutional 


\section{MANAGEMENT}

Research, Planning, and Effectiveness briefly shared library space before moving offsite. Currently the library additionally houses computer and digital media labs, a one-button studio, and individual and group study spaces; it also shares space with the campus's Learning Center and the new Executive Leadership Team. These new programs and units have required a new staffing model.

\section{CHANGING ORGANIZATIONAL STRUCTURE}

When I started at HCC the year after the library's move to its current building, I had just two major duties: processing and managing all interlibrary loan functions and helping to staff the Digital Library Desk, which for a brief time was costaffed by the library and Computer Technology Services. I began as a paraprofessional who did not yet have an MLS degree. The library employed approximately six librarians and a combined thirteen library assistants and technicians, led by an administrative team. Eventually, the Digital Library Desk was moved under eLearning and renamed the Distance Learning Desk, and library staff no longer helped to staff it. ${ }^{2}$ Under new library leadership, some library technicians retired or were internally reclassified as exempt positions as library services evolved. Once I had my MLS, I assumed the role of cataloging advisor. Later, I became manager for technical services/government documents librarian, inheriting the depository coordinator role when that librarian retired. A manager for circulation and acquisitions was hired, my counterpart once the technical services supervisor position was split into two professional positions.

Today I am one of two managers who work collaboratively to oversee services performed by employees crosstrained in the technical services and circulation processes. My main responsibilities are supervising processing and cataloging for all new materials. I also oversee all interlibrary loan functions and help train staff in services that form the backbone of technical services. As a professional librarian, I have assigned shifts at the reference desk. As depository coordinator, I supervise our Catalog Record Distribution Program (CRDP) profile and manage our item-selection profile. At a larger academic library, my array of duties would be parceled out to various specialized librarians, but my library affords me the opportunity to develop expertise in a variety of areas.

At my institution, there is clearly movement to meet principle and performance indicator number 8.8 of ACRL's Standards for Libraries in Higher Education: "Library personnel continuously examine and transform roles to meet the needs of the evolving organization." ${ }^{3}$ Our library services now include three newer initiatives: the Library Computer Lab Desk (former Distance Learning Desk, given back to the library from eLearning); the Digital Media Lab/One Button Studio; and the preservation of the historic Hays-Heighe House, a campus structure that serves as an extension of the library as exhibit, classroom, and educational program space. Positions once assigned to technical services have been reallocated to support these service priorities. The Library Computer Lab Desk is staffed predominately by student workers, along with new Digital Media staff in reallocated positions. Cataloging duties have been parceled out to more part-time staff. Records for e-books and government documents are batch imported from vendors, and there is discussion that eventually more of our technical services processes will be transferred to vendors to be received as "shelf-ready" materials.

\section{REDISTRIBUTION OF DUTIES}

It is sometimes difficult to describe this intertwined mesh of circulation and technical services that is supervised by two managers and mainly performed by paraprofessionals. Processing is a shared responsibility. I process interlibrary loan requests and have trained three of the library assistants for this work, even though only two of those employees are my direct reports. I still oversee and train in all aspects of technical services support, working in collaboration with the manager of circulation and acquisitions to devise a schedule around the circulation duties that most of these library staff members perform under his direct supervision. Responsibility for cataloging the physical collections (print, nonprint, equipment, course reserves, specialty items, and government documents) rests with this combined circulation and technical services staff. Our library systems specialist, also in technical services, handles most of the e-book-record batch downloads into our catalog. Further cross-training exists among newer reclassified professional positions regarding our OCLC, e-book, Marcive, digital media, and archive services.

Staff routinely collaborate to cover other duties and services. Many of the full-time professional library staff titles are long and separated by slashes or conjunctions to describe the many hats that are worn. The silver lining is that they are not as separated into working silos, unlike in many libraries. Because of training across all aspects of library services, essential job functions and service desks can always be covered during both planned and unexpected absences.

HCC Library appears to be on the higher end of FTE staff compared with libraries at other Maryland community colleges that similarly have just one campus. ${ }^{4}$ Our circulation desk, supervised by the manager for circulation and acquisitions, serves as what is typically known as access services in other libraries. It is staffed by a rotation of eight full- and part-time staff, including those who also work in technical services or the Digital Media Lab. Our public services, which we call Reference, fall under the direction of the assistant director for the library/collection development and reference. They are covered by a rotation of eight professional librarians, including me, serving at the reference desk and teaching information literacy. At the request of the administration, the library recently submitted a staffing analysis, requesting 
replacement of a library assistant who transferred to another department on campus and permission to hire as-needed reference librarians.

Now HCC Library still has three service points: circulation and reference desks located side-by-side and a Library Computer Lab desk. But there is an increasing cross-training and collaboration initiative underway for all three of these desks, especially during busy times. The reserves area at the circulation desk has grown beyond maintaining books for instructors; it now houses a large textbook reserve collection, multiple anatomical models for our vibrant nursing program, and a range of popular equipment from graphing calculators and laptops to digital cameras and tripods, all available for checkout. The college is moving toward a learning commons environment, and the current college president sees the library as the "heartbeat of the campus."

\section{SERVING COMMUNITIES AND PROMOTING SERVICES}

Although some similar institutions in Maryland have dropped the term "community" from their names, HCC has kept it. ${ }^{6}$ The reason may be seen in HCC's values of service ("We are accessible and responsive to our students, our community, and each other. Helping people achieve their goals is central to our mission") and collaboration ("We foster teamwork and partnerships. Working together enhances results and builds community.") ${ }^{7}$

By way of collaboration between our campus and the surrounding community, for years HCC Library and the county public library system have jointly covered the cost for a shared online public access catalog that supports reciprocal borrowing and a courier service for materials between our campus library and the twelve public library branches in Harford County. In addition to our campus student and staff patrons, those with the status of Community Borrower are entitled to circulation privileges, free access to government information, interlibrary loan, and reference services.

The Library Marketing and Programming Committee promotes services to the campus community each year, such as National Library Week events. Most professional library staff offer numerous workshops at Faculty Professional Development Days before the start of fall semester annually, showcasing our access points to library resources. Librarians are embedded into Blackboard courses and work with faculty in collection-mapping projects intended to streamline collection development with curriculum and course offerings.

All library staff who show an interest also help promote the library's services in the community. HCC Library raises awareness of borrowing privileges in county public libraries by providing library literature and giveaways in goodie bags to young patrons in the public library summer reading program. Staff help at promotional tables during the kickoff day event. Instructional librarians have collaborated with Harford County Public Schools' media specialists on ways to help better prepare high school students for college-level research. HCC promoted access to government information with the recent fiftieth anniversary celebration of our involvement in the Federal Depository Library Program at an event that saw attendance by several state and county government officials. Staff collaborate with the campus Office of Student Life and the Paralegal Student Association each year to observe Constitution Day.

\section{COMMUNITY OF COLLABORATION}

Throughout my years at the HCC Library, and despite the changes in duties, titles, and responsibilities, one thing has remained constant: the feeling of family. In our roles wearing many hats and juggling many tasks, it takes a close-knit, collaborative team to do right by our community of users. It also takes flexibility and compassion for each other so that personal needs are met along with professional ones. This is where cross-training is essential to ensure that every staff member is knowledgeable about others' work and able to fill in where needed without the loss of excellent customer service. Reallocation and reclassification of job titles and providing professional development opportunities to both full- and part-time staff is essential. The library's values run parallel to those of our institution: "We value teamwork and seek to build effective partnerships within our division, on our campus, and with local, national and global communities."

\section{References}

1. Pam Schott, "Harford Community College Library: A Brief History," manuscript, January 20, 2010, Published on the Occasion of the Tenth Anniversary of the Library Building, Harford Community College Board of Trustees.

2. Schott, "Harford Community College Library."

3. Association of College and Research Libraries Board of Directors, Standards for Libraries in Higher Education (Chicago: Association of College and Research Libraries, 2018).

4. "Use the Data," National Center for Education Statistics, Integrated Postsecondary Education Data System, 2016, nces. ed.gov/ipeds/datacenter/InstitutionList.aspx; "Library Statistics Program: Compare Academic Libraries," National Center for Education Statistics, 2012, https://nces.ed.gov/surveys/libraries /Compare/Default.aspx.

5. "Achieving the Dream-Harford Community College," Achieving the Dream, 2018, https://www.achievingthedream.org/college _profile/17321/harford-community-college.

6. "The Colleges," Maryland Community Colleges, 2016, https:// mdacc.org/the-colleges/.

7. "Mission, Vision, Values," Harford Community College, 2018, http://www.harford.edu/about/mission.aspx.

8. "Mission, Vision, Values," Harford Community College Library, 2018, http://www.harford.edu/academics/library/about/mission -vision-and-values.aspx. 